\title{
Overcoming Challenges in English for Aviation Maintenance: Technical Publications Selection for the Construction of a Corpus and Its Use to Teach Language Aspects Considering Learners Needs
}

\author{
Daniela Terenzi \\ Federal Institute of Education, Science and Technology of São Paulo-IFSP, University of São Paulo-USP, \\ São Carlos, Brazil \\ Email: daniela.terenzi@ifsp.edu.br
}

How to cite this paper: Terenzi, D. (2021) Overcoming Challenges in English for Aviation Maintenance: Technical Publications Selection for the Construction of a Corpus and Its Use to Teach Language Aspects Considering Learners Needs. Open Journal of Applied Sciences, 11, 1122-1134

https://doi.org/10.4236/ojapps.2021.1110084

Received: September 15, 2021

Accepted: October 23, 2021

Published: October 26, 2021

Copyright $\odot 2021$ by author(s) and Scientific Research Publishing Inc. This work is licensed under the Creative Commons Attribution International License (CC BY 4.0).

http://creativecommons.org/licenses/by/4.0/

(c) (i) Open Access

\begin{abstract}
Aviation English and Corpus Linguistics have been put together and focused by some investigations especially those regarding Aeronautical English (the language used between pilots and air traffic controllers in international radiotelephony communications). However, English used in aviation maintenance, specifically in written documents, has not been as much researched. This paper briefly explains the main concepts considering Aviation English and presents-based on previous researches-aircraft maintenance professionals' needs and regulatory agencies' requirements related to language proficiency. Afterwards, it summarizes information about the most important technical publications for aircraft maintenance and describes the compilation of the Corpus of documents related to aviation maintenance (CoDoRAM). At the end, some ways the corpus can be used to teach vocabulary and grammar in English are pointed out. Although corpus compilation and analysis have been proved to be valuable for research and instructional purposes, most of publications encompass English for academic purposes teaching context. For that reason, this is a way to inspire new projects related to English used in aviation maintenance and the use of corpora in English for specific purposes classes.
\end{abstract}

\section{Keywords}

English for Specific Purposes, Aviation Maintenance, Technical Publications, Corpus Compilation and Analysis, Teaching Challenges 


\section{Introduction}

English is officially the "language of the skies" considering it is the most globalized sector of industry and professionals of this area such as pilots, mechanics, engineers and air traffic controllers (ATCs) not only need but are also demanded to use English to communicate in oral and written situations [1] [2] [3] [4].

Although it may seem English for aviation is a single package for the whole field, that is not the reality and even the use of some terms can be confusing. Aviation English is a broad term, but it is usually adopted to refer to the language used between pilots and air traffic controllers in international radiotelephony communications and this specific usage definitely does not encompass all the language varieties used by the different professionals of the area. Like in Tosqui-Lucks and Silva [5], throughout this paper, aviation English is used as the "umbrella term" while aeronautical English determines the language for communications that take place during a flight in an international context.

Taking aviation field and language into consideration, it is important to keep in mind other two concepts, phraseology and plain English. Tosqui-Lucks and Silva [6], as a translation of Scaramucci, Tosqui-Lucks and Damião [1] definitions, defined the first one as "a code used by pilots and air traffic controllers [...] characterized by short phrases and reduced vocabulary" (p.14) used for transmitting information related to the flight. Also according to them, plain English is the use of the language "in radiotelephony communication that exceeds the use of standard Phraseology, when it is not sufficient, but that should mirror phraseology, keeping its characteristics and specificities" (p.14) without jeopardizing intelligibility, non-ambiguity and concision.

Aeronautical English, standard phraseology and plain English have been focused by aviation organizations, regulatory agencies, researchers and teaching material developers for decades but there is a totally different scenario considering communication among maintenance professionals such as technicians and mechanics. There are still few standards and rules related to language proficiency, tests, studies and teaching materials whose priority is English for aviation maintenance.

These are some of the challenges pre- and in-service professionals, language teachers and Maintenance Repair and Operations/Overhaul (MRO) companies have faced over the years. Although compiling a corpus for a specific purpose and using the results of its analysis in teaching environment is not a recent enterprise, the number of researches and the use of their outcomes in real scenarios in the field of aviation English is not satisfactory yet. Some studies, as those presented in Bocorny [7] and Tosqui-Lucks [8], have proven the combination of corpus linguistics and aviation English is beneficial to understand language aspects and to help teachers and learners. However, the great majority of the investigations has focused on aeronautical English, what shows there is still a huge gap regarding English used in aviation maintenance.

The aim of this article is to describe the most important technical documents 
in aviation maintenance which were chosen to be part of the corpus. Besides that, it is presented how different types of analysis might point out solutions to challenges of understanding, choosing and teaching specific language aspects. It is based on the experience of compiling a corpus considering maintainers' needs, lacks and wants [9] and demands of regulatory agencies from The United States of America and Brazil.

In the following, Section 2 presents aircraft maintenance professionals' needs and regulatory agencies' requirements based on studies and regulations and, then, in Section 3 the main challenges considering English for aviation maintenance are pointed out. Afterwards, in Section 4, the relation between aviation English and corpus linguistics is shown considering some researches that have been done specially in Brazil. Aviation maintenance technical documents and the corpus compilation are explained in Section 5 and that precedes the ideas of how the CoDoRAM might be helpful to teach English vocabulary and grammar aspects presented in Section 6. The paper is closed, in Section 7, with a conclusion and references are presented after it.

\section{Aircraft Maintenance Professionals' Needs and Regulatory Agencies' Requirements}

As far as we are aware, there are only three studies which aimed at analyzing aircraft maintenance professionals' needs, Terenzi [10], whose results are also presented in Terenzi and Augusto-Navarro [11], Niamsuwan [12] and Embryany and Ratmanida [13]. All the authors emphasize workers from different areas in aviation have particular demands when it comes to language use as stated by Embryany and Ratmanida [13]: "English needs for the aircraft maintenance are different from other divisions, such as pilots, ATCs, or flight attendants, which are based on the performed tasks" (p. 35).

It is known the main jobs of the maintenance are maintaining and repairing the aircraft, and "to perform the tasks the workers must follow certain task card or job card that are in English" [13] (p. 36). However, cards are not the only type of document engineers, mechanics and technicians are supposed to deal with on a daily basis. Terenzi and Pizzi [3] mentioned some of those documents and the ones used in our corpus will be described later in this paper.

The most important skill for maintenance workers is reading [10] [11] [12] [13] and it is used to understand technical manuals, instructions, reports, statistic data, and many other documents. The second most required skill in aviation maintenance is writing since all tasks must be recorded and, although they are not essential in this scenario, listening and speaking are also relevant skills as they favors better career opportunities and remuneration, possibilities of traveling abroad and of reaching higher career levels [10].

Even though the researchers pointed out the most common needs and wants for aviation maintenance professionals, studies have discussed language and safety issues [14] [15] and it is common sense English is vital in all fields of aviation, aeronautical authorities have not yet prescribed procedures for both training and 
testing of English for maintainers.

According to the Electronic Code of Federal Regulations (eCFR), written by the Federal Aviation Administration [16] in which there is information about the Eligibility Requirements for United States mechanics (Title 14 Aeronautics and Space $\rightarrow$ Part 65 Certification: airmen other than flight crewmembers $\rightarrow$ Subpart D-Mechanics $\rightarrow \$ 65.71$ Eligibility requirements: General), "to be eligible for a mechanic certificate and associated ratings, a person must- $[. .$.$] (2) Be$ able to read, write, speak, and understand the English language". In the same document, "a certificated repair station must ensure its supervisors [inspectors] understand, read, and write English. (Part 145 Repair station $\rightarrow$ Subpart DPersonnel $\rightarrow \$ 145.153 / \$ 145.155)$.

The American aviation agency, as cited above, requires personnel to know English but there is no specification on mandatory language aspects such as vocabulary or grammar professionals should be able to understand/use and no obligation of a test which would assess their language proficiency, not to mention there is no information on criteria to evaluate if the employee is able to understand, read, and write English as required.

In Brazil, the National Civil Aviation Agency (Agência Nacional de Aviação Civil-ANAC) stablishes the contents for a certified aviation maintenance mechanic program and it is mandatory for the students to have English classes during their training. The instruction-IS 141-002A [17]-is the document that specifies course goals, content and learning outcomes. According to it, knowing basic grammar aspects, specific vocabulary and how to understand technical publications are objectives to be achieved by students. Although Brazilian instructions are a little more specific than FAA requirements, it is still a challenge for teachers to determine what will be covered during a course.

\section{Challenges Considering English for Aviation Maintenance}

The International Civil Aviation Organization (ICAO) has stablished Standards and Recommended Practices (SARPs) concerning language proficiency requirements since 2010. However, the focus of ICAO language proficiency requirements is on improving aeronautical radiotelephony communications and there are no such guidelines considering other uses of aviation English.

That probably is the greatest challenge considering English for aviation maintenance since SARPs are used worldwide as a guide for material development, teaching and testing and they only include directions for communication over the radio among fight crew members and air traffic controllers.

In this scenario, it is not difficult to find course books focusing on English for aviation, but the truth is all of them are about aeronautical English as in English for Aviation: for pilots and Traffic Controllers [18], Aviation English: for ICAO compliance [19] and Flightpath: Aviation English for Pilots and ATCOs [20].

Although these materials offer activities that aim at giving students opportunities to practice authentic communication situations based on the requirements previously stablished by the ICAO, language teachers, students and even profes- 
sionals cannot rely on these materials to study and teach English specifically used in aviation maintenance field [3]. The referred materials are not suitable for maintainers not only because of the difference in language use among the professionals but also due to the fact the functions, structures, qualifications and levels considering English have not been determined for maintenance area.

For teachers, even though they are able to understand professionals' needs, lacks and wants, another difficulty is to select genres and language aspects to be focused during classes. At the same time, they are also challenged to deal with terms and concepts from an area that is not their expertise [21].

Just to give an idea about that challenge, there are almost 100 chapters and about 34,000 pages in only one aircraft maintenance manual. Each chapter is about a different part of the aircraft, such as landing gears, windows, doors, etc. Moreover, maintenance manuals are not the only documents professional are supposed to use daily, they are supposed to understand accident reports, advisory circulars, job cards and many others.

Therefore, without guidance, it is a tough task for language teachers to select what to teach in this type of course, especially if she has never had contact with such documents and might not be used to mechanics' job routine. As it has been done in other areas, corpus linguistics has proven to be a way to overcome some language issues considering aeronautical English, as we are going to present in the next section, but its use in aviation maintenance is still incipient.

\section{Aviation English and Corpus Linguistics}

The jargon used in aviation contains thousands of technical terms in English [22] [23] and due to the low number of investigations about them, the study of terminology also becomes a challenge. Researches in Brazil have focused on understanding aviation specific vocabulary based on corpus [24] [25] [26].

Brazilian researchers have conducted other corpus-based investigations related to aviation, such as Prado [27] [28] [29] who addressed aspects of the oral language used by pilots in abnormal situations, with a focus on lexico-grammatical and pragmatic patterns. The results of Santos [30]' research also contribute to understand lexical terms used in emergency situations, as well as offer "a broader idea for the purposes of teaching material, pilot training and other purposes" (p. 190).

Also in Brazil, other studies were developed in the aeronautical area and based on corpus, such as those by Gabrielatos and Sarmento [31] and by Sarmento [32], which aimed to quantify and analyze the modal verbs used in manuals. Also based on a corpus of manuals, Bocorny [33] [34] analysis helped to understand polylexical units in this type of document. In addition to these studies, those by Zuppardo [35] and Prado and Tosqui-Lucks [36] were also based on the theoretical-methodological assumptions of corpus linguistics.

Thus, the study of English in aviation context through corpus linguistics approach has significantly contributed to teaching and learning. This type of research is important for teachers to select and understand language aspects, but 
just a few has effectively and directly applied corpus to teaching (Data-driven learning, for example) and assessment [8].

Considering this theoretical foundation, it is undeniable that a corpus of technical documentation used in aircraft maintenance might contribute to teachers and students in teaching and learning English for this specific purpose. Based on these arguments, most important documents, which were selected to be in the corpus, are presented hereafter.

\section{Aviation Maintenance Technical Documents and the Corpus}

Sarmento [37] states that in the case of a corpus with a very specific theme, such as in the aviation area, it is up to the researcher to compile the texts based on a specific research project in mind, such as the production of teaching material. There is no limit to the size of the corpus or degree of specialization involved, but the parameters for limiting the type of text, oral or written, must be very well established.

So, taking into consideration all the aspects related to English used in aviation maintenance field, the criteria for building the corpus were: 1) the most important skill for professionals, i.e., reading; 2) the most important documents related to maintenance practice; 3) availability of the texts and 4) variety of genres. Before presenting the data about the corpus, a brief explanation on each type of selected document is given.

Zafiharimalala and Tricot [38] explain that aviation documents used in maintenance have three main functions, they provide support to professionals to perform tasks, they are legal documents for recording the actions performed and they are used for training. The most popular one is the Aircraft Maintenance Manual, known by its acronym AMM. It is provided by aircraft manufacturers to guide how to perform specific tasks and is usually used by technicians and mechanics. Predominantly, it is written in imperative form as it is a set of guidelines for maintenance duties such as inspection, cleaning, repair, and replacement of damaged or malfunctioning components.

Another very common type of manual is the Component Maintenance Manual $(\mathrm{CMM})$. It is issued by the manufacturer of a specific component and defines the maintenance actions that must be performed. This manual is also used by mechanics with technical or technological training and its characteristics are similar to the AMM's. Aircraft Operating Manuals (AOM) are used by all aviation professionals and by students for training. It is a document in which each aircraft equipment or system is detailed, and its operation is explained. The text, in general, is written in the present tense, as it is descriptive and very objective, without the use of figures of speech and there are few occurrences of reference elements, such as pronouns, for example.

Other documents are published by regulatory agencies, such as ANAC and the FAA. Airworthiness Directives (AD), for example, are legally enforceable rules to correct an unsafe condition in a product. Advisory Circulars (AC) refer to a type 
of publication made by the FAA to provide guidance on compliance with airworthiness regulations, pilot certification, operational standards, training standards and other rules.

Aviation Accident Reports provide date, time, location, people and aircraft involved, nature of the event and all pertinent details of an incident or accident. They are widely known documents used in aviation and are written as reports, including the sequence of facts and transcripts of conversations (between crew and air traffic controllers, for example) as well as the mainly verbal forms used are those to report facts that occurred (such as simple past and past perfect).

Forms, in which all types of information about an aircraft and its maintenance are provided, are also very important documents in aviation specially because all communication among the company's sectors is done though them. The Logbook is another well-known document as it is the official record of all data related to the aircraft. The information available in this book is used to determine the condition of the aircraft, date of inspections, etc.

In addition to these documents, there are others such as the Aircraft's Flight Manual (full of instructions, used mainly by pilots), the Airworthiness Certificate (which approves the aircraft to fly) and all the professionals' personal documentation, such as the certificates issued by ANAC and FAA. It is important to mention that most of the documents are free to be accessed and downloaded, especially those issued by national and international agencies, and some of them are restricted so to be part of this corpus they were provided by a MRO company as a collaborative action to our project. Information about documents availability will be provided along with corpus description.

Considering the corpus will be used for different purposes, such as researching and teaching language aspects related to specific vocabulary and frequent grammar structures and for Data Driven Learning (DDL), documents were selected based on their use and relevance in aviation maintenance. The selected materials, their availability/source, publication date and the number of tokens (the number of individual words in the text) and types (the number of unique word forms) are shown in Table 1.

It should be emphasized, as it was done by Prado and Tosqui-Lucks [39] about their corpus, that this corpus also focuses on a very specific area, the aircraft maintenance. Considering it is within a particular field, the aviation, it might not only enable linguistic investigations but also "offer the opportunity to bring authentic language to the classroom, supplying the language professional with adequate tools to teach from meaningful input" [39] (p. 125).

\section{Uses of the CoDoRAM to Teach English Vocabulary and Grammar Aspects}

Wang [40], who presented information on construction and application of an aircraft manufacturing engineering English corpus, points out "a large number of real language use examples in the corpus can provide scientific guidance for the design of syllabus [...]" (p.294) and that is one of the applications we intend 
Table 1. Corpus of documents related to aviation maintenance (CoDoRAM).

\begin{tabular}{|c|c|c|c|c|c|}
\hline DOCUMENT & AVAILABILITY & PUBLISHED BY & PUBLICATION DATE & TOKENS & TYPES \\
\hline Airworthiness Directives & $\begin{array}{l}\text { https://www.faa.gov/regulations_polici } \\
\text { es/airworthiness_directives/ }\end{array}$ & ${ }^{\mathrm{Fi}} \mathrm{FA}$ & $\begin{array}{l}\text { issued in last } 60 \text { days-on } \\
01 / 11 / 2021\end{array}$ & 183,297 & 4460 \\
\hline $\begin{array}{l}\text { Aircraft Maintenance Manual } \\
\text {-A319 }\end{array}$ & $\begin{array}{l}1 \text { Restricted-provided by a MRO } \\
\text { company (R-MRO) }\end{array}$ & Airbus & 2012 & $13,250,428$ & 24,599 \\
\hline $\begin{array}{l}\text { Aircraft Maintenance Manual } \\
\text {-A330 }\end{array}$ & R-MRO & Airbus & 2011 & $8,532,432$ & 18,481 \\
\hline $\begin{array}{l}\text { Aircraft Maintenance Manual } \\
\text {-B737 }\end{array}$ & R-MRO & The Boeing Company & 2005 & $2,595,840$ & 13,828 \\
\hline $\begin{array}{l}\text { Aircraft Maintenance Manual } \\
\text {-B767 }\end{array}$ & R-MRO & The Boeing Company & 2010 & 180,595 & 3320 \\
\hline $\begin{array}{l}\text { Aircraft Maintenance Manual } \\
\text {-Cessna }\end{array}$ & R-MRO & Cessna Aircraft Company & 2002 & 131,613 & 5949 \\
\hline $\begin{array}{l}\text { Aircraft Maintenance Manual } \\
\text {-EMB190.195 }\end{array}$ & R-MRO & Embraer S.A. & 2017 & 221,227 & 4425 \\
\hline $\begin{array}{l}\text { Aircraft Operating } \\
\text { Manual-B737 }\end{array}$ & R-MRO & The Boeing Company & 2018 & 645,854 & 7099 \\
\hline $\begin{array}{l}\text { Aircraft Operating } \\
\text { Manual-EMB190.195 }\end{array}$ & R-MRO & Embraer S.A. & 2017 & 773,303 & 20,944 \\
\hline $\begin{array}{l}\text { Reports } \\
\text { (ASRM: Aviation Safety } \\
\text { Reporting System) }\end{array}$ & $\begin{array}{l}\text { https://asrs.arc.nasa.gov/search/databa } \\
\underline{\text { se.html }}\end{array}$ & $\begin{array}{l}\text { aNASA (National Aeronautics } \\
\text { and Space Administration) }\end{array}$ & $\begin{array}{l}\text { thirty }(30) \text { ASRS } \\
\text { Database Report Sets on } \\
01 / 11 / 2021\end{array}$ & 952,913 & 12,316 \\
\hline Magazine & https://www.avm-mag.com/ & $\begin{array}{l}\text { Aviation Maintenance } \\
\text { Magazine }\end{array}$ & $\begin{array}{l}\text { All issues: from } 2010 \text { to } \\
2020\end{array}$ & $1,744,543$ & 35,909 \\
\hline Accident Reports & $\begin{array}{l}\text { http://sistema.cenipa.aer.mil.br/cenipa } \\
\text { /paginas/relatorios/relatorios.php }\end{array}$ & $\begin{array}{l}\text { CENIPA } \\
\text { aeronautical Accidents } \\
\text { Investigation and Prevention } \\
\text { Center in Brazil) }\end{array}$ & From 1962 to 2020 & 55,135 & 3927 \\
\hline Airworthiness Directives & $\begin{array}{l}\text { https://sistemas.anac.gov.br/certificaca } \\
\text { o/DA/DA.asp }\end{array}$ & aNAC & From 1915 to 2020 & 236,558 & 5067 \\
\hline Handbooks and Manuals & $\begin{array}{l}\text { https://www.faa.gov/regulations_polici } \\
\text { es/handbooks_manuals/aviation/ }\end{array}$ & ${ }_{\mathrm{FAA}}$ & 2000 and 2018 & $1,030,684$ & 18,248 \\
\hline Engine Manuals & https://jabiru.net.au/service/manuals/ & $\begin{array}{l}\text { Jabiru Aircraft Pty Ltd } \\
\text { (Australian aircraft } \\
\text { manufacturer) }\end{array}$ & Different dates & $1,219,589$ & 8325 \\
\hline Accident Reports & $\begin{array}{l}\text { https://www.ntsb.gov/investigations/A } \\
\underline{\text { ccidentReports/Pages/aviation.aspx }}\end{array}$ & $\begin{array}{l}\text { NSTB (National } \\
\text { Transportation Safety Board- } \\
\text { US) }\end{array}$ & $\begin{array}{l}\text { Reports issued since } 1996 \\
\text { up to } 01 / 03 / 2021\end{array}$ & $62,186,525$ & 24,239 \\
\hline $\begin{array}{l}\text { Structure Repair Manual- } \\
\text { A320 }\end{array}$ & R-MRO & Airbus & 2014 & $2,724,590$ & 12,467 \\
\hline $\begin{array}{l}\text { Structure Repair Manual- } \\
\text { B737 }\end{array}$ & R-MRO & The Boeing Company & 2002 & 441,900 & 9229 \\
\hline $\begin{array}{l}\text { Trouble Shooting Manual- } \\
\text { A320 }\end{array}$ & R-MRO & Airbus & 2008 & $7,146,123$ & 7031 \\
\hline Total & & & & $44,253,149$ & 239,863 \\
\hline
\end{tabular}


to use the CoDoRAM for. Prado [41] had made the same point explicit saying the selection of the most common language chunks will show what content is to be taught.

Some studies [41] [42] [43] [44] have given ideas of how to use corpora for classroom applications. Some of them include turning concordance lines and other corpus data into activities, having a useful source of authentic language examples, enabling students to be researchers and form preliminary hypotheses about vocabulary and grammar uses. The cited authors defend that opportunity of inferring rules might lead to a more autonomous learning process. Examples to be presented are, therefore, related to the specific use of the CoDoRAM in an English for aviation maintenance teaching/learning context.

Considering the number of documents and their size, corpus analysis can be done in order to help teacher select the text, or an excerpt of it, to be used in a specific class. This selection can be guided by using concordance plot tool of Antconc [45], for instance. Because of their equal translation in Portuguese, students have problems in understanding the difference between some words such as "charge"/"load" (both are translated as "carga" in Portuguese), and "electric"/"electrical" ("elétrico") and the analysis of most common clusters with these terms helps them to discern the distinction, an adapted for classroom research activity similar to what was investigated by Costa and Camargo [25] regarding "safety" and "security" ("segurança").

The AMM and CMM are, in a simple way, sets of instructions and that is why verbs are so relevant for students and professionals to know in order to understand these publications. However, it would be hard to study many verbs based on a reading comprehension activity with an excerpt of them. Corpus analysis of these documents provides a list of the most frequent words-by using word/ keyword list tool of Antconc [45], for example-and verbs can be highlighted by the teacher as well as their context of use (in concordance lines) aiming to offer students the opportunity to learn several verbs they will come across while following directions in the manuals.

Learners sometimes struggle with understanding noun strings, as it has been observed in classes, and when they are given guidance to explore the corpus using key words, such as system and valve, they might infer how to organize a cluster to give details/characteristics about its head noun (e.g. hydraulic system and shutoff valve). Another grammar aspect Brazilian English learners usually have problems with are the prepositions and it is helpful to use real examples from the corpus so they are able to study the most frequent co-texts and understand the differences of using each of them.

These are just some ideas of how the CoDoRAM can be explored and used for teaching and learning English for the specific purpose of reading and understand aviation maintenance technical publications. It is clear that the corpus analysis is not restricted to these mentioned points because there is a wide range of language aspects that can be investigated and there are many possibilities and dif- 
ferent ways of using not only corpus analysis results but also the corpus exploration itself during classes.

\section{Conclusions}

This paper introduced the CoDoRAM and explained the most relevant technical publications in aviation maintenance field which were chosen to be part of the corpus. All the information presented can be used as a guide for English learners and teachers in order to understand the documentation of this area and as an inspiration to other language for specific purposes teachers considering corpora compilation, analysis and use inside their classrooms.

There is still much to be done considering corpus analysis in this specific area and their results in order to give teachers the opportunity to have a broader comprehension about linguistic features and to make informed decisions regarding classes and their contents. Besides that, there is a lack of studies regarding learners' performance and attitude when they are guided to explore corpora to learn English for a specific purpose.

\section{Acknowledgements}

The author wishes to acknowledge the MRO company for providing some of the documents used to compile the corpus, professor Dr. Stella Esther Ortweiler Tagnin (University of São Paulo-USP) for supervising the postdoctoral research for which the CoDoRAM is being used and the members of GEIA-Grupo de Estudos em Inglês Aeronáutico (Aeronautical English Research Group)—and GPIMAGrupo de Pesquisa em Inglês para Manutenção de Aeronaves (English for Aviation Maintenance Research Group)—who have played an important role not only providing great opportunities for discussing aviation English importance, use, teaching and learning but also for inspiring and supporting the studies related to English for aircraft maintenance personnel.

\section{Conflicts of Interest}

The author declares no conflicts of interest regarding the publication of this paper.

\section{References}

[1] Scaramucci, M.V.R., Tosqui-Lucks, P. and Damião, S.M. (Eds.) (2018) Pesquisas sobre inglês aeronáutico no Brasil. Pontes Editores, Campinas.

[2] Tosqui-Lucks, P. and Prado, M.C. (2020) New Routes in the Study of Aviation and Aeronautical English. The Especialist, 41, 1-4. https://doi.org/10.23925/2318-7115.2020v41i4a1

[3] Terenzi, D. and Pizzi, M.C.B. (2020) The Relevance of Linguistic and Professional Knowledge as Contributing Factors for Technical Translation in the Area of Aircraft (Maintenance). The Especialist, 41, 1-16. https://doi.org/10.23925/2318-7115.2020v41i3a9

[4] Carvalho, M. and Prado, D.A. (2021) Corpora de inglês aeronáutico: Desafios para 
o estudo da área e proposta de trabalho conjunto. Tradterm, 37, 148-174.

[5] Tosqui-Lucks, P. and Silva, A.L.B.C. (2020) Aeronautical English: Investigating the Nature of This Specific Language in Search of New Heights. The Especialist, 41, 1-27. https://doi.org/10.23925/2318-7115.2020v41i3a2

[6] Tosqui-Lucks, P. and Silva, A.L.B.C. (2020) Da elaboração de um glossário colaborativo à discussão sobre os termos "inglês para aviação" e "inglês aeronáutico". Estudos Linguísticos, 49, 97-116. https://doi.org/10.21165/el.v49i1.2561

[7] Bocorny, A.E.P. (2011) Panorama dos estudos sobre a linguagem da aviação. Revista Brasileira de Lingüística Aplicada, 11, 963-986. https://doi.org/10.1590/S1984-63982011000400009

[8] Tosqui-Lucks, P. (2018) Aplicações de corpora no ensino e na avaliação de inglês aeronáutico: Estado da arte, reflexões, direcionamentos. In: Scaramucci, M.V.R., Tosqui-Lucks, P. and Damião, S.M., Eds., Pesquisas sobre inglês aeronáutico no Brasil, Pontes Editores, Campinas, 89-111.

[9] Hutchinson, T. and Waters, A. (1987) English for Specific Purposes: A LearningCentred Approach. Cambridge University Press, Cambridge.

[10] Terenzi, D. (2014) Princípios norteadores para o planejamento de cursos de línguas para propósitos específicos em curso superior tecnológico (manutenção de aeronaves): Considerando visões de aprendizes, instituição formadora e empregadores. Doctoral Dissertation, Universidade Federal de São Carlos, São Carlos.

[11] Terenzi, D. and Augusto-Navarro, E.A.H. (2018) Planejamento de cursos de língua para propósitos específicos (instrumental) em cursos superiores tecnológicos: Reflexões e estabelecimento de princípios norteadores com base em curso de tecnologia de manutenção de aeronaves. In: Barbirato, R. and da Silva, V.L.T., Eds., Planejamento de cursos de línguas. Traçando rotas, explorando caminhos, Pontes Editores, Campinas, 17-48.

[12] Niamsuwan, P.M. (2017) A Study of Needs Analysis of English Language for Aircraft Heavy Maintenance Mechanics. Master's Thesis, Thammasat University, Phra Nakhon.

[13] Embryany, F. and Ratmanida, R. (2020) A Need Analysis of English Learning for the Aircraft Maintenance Students. Proceedings of the 1 st International Conference on Lifelong Learning and Education for Sustainability (ICLLES 2019), Padang, 35-39. https://doi.org/10.2991/assehr.k.200217.008

[14] Drury, C.G., Guy, K.P. and Wenner, C.A. (2010) Outsourcing Aviation Maintenance: Human Factors Implications, Specifically for Communications. International Journal of Aviation Psychology, 20, 124-143. https://doi.org/10.1080/10508411003617771

[15] Ma, J., Drury, C.G. and Marin, C.V. (2010) Language Error in Aviation Maintenance: Quantifying the Issues and Interventions in Four World Regions. International Journal of Aviation Psychology, 20, 25-47. https://doi.org/10.1080/10508410903416136

[16] Federal Aviation Administration (2021) Electronic Code of Federal Regulations. https://www.ecfr.gov/cgi-bin/text-idx?SID=a0e517720ebe77d483ce383b38188c98\& mc=true\&tpl=/ecfrbrowse/Title14/14tab 02.tpl

[17] Agência Nacional de Aviação Civil (2018) Instrução Suplementar 141-002A. https://www.anac.gov.br/assuntos/legislacao/legislacao-1/boletim-de-pessoal/2018/1 0/anexo-vi-is-no-141-002-revisao-b

[18] Ellis, S. and Gerighty, T. (2008) English for Aviation: For Pilots and Traffic Controllers. Oxford University Press, Oxford. 
[19] Emery, H. and Roberts, A. (2008) Aviation English: For ICAO Compliance. Macmillan Education, London.

[20] Shawcross, P. (2011) Flightpath: Aviation English for Pilots and ATCOs. Cambridge University Press, Cambridge.

[21] Monzón, A.J.B. and Fadanelli, S.B. (2016) Leitura de textos especializados anglófonos no Ensino Técnico: Idiossincrasias terminológicas e pedagógicas sob a perspectiva da Linguística de Corpus. LínguaTec, 1, 1-28. https://doi.org/10.35819/linguatec.v1.n1.a582

[22] Ribeiro, G.C.B. (2004) Tradução técnica, terminologia e linguística de corpus: A ferramenta Wordsmith Tools. Cadernos de Tradução, 2, 159-174.

[23] Muller, A.F. and Rabello, C. (2013) A terminologia presente no interior das empresas: Um estudo de caso sobre a variação terminológica em uma empresa de manutenção, reparo e revisão de aeronaves (MRO). ReVEL, 11, 50-62.

[24] Rabello, C. and Muller, A.F. (2012) A tradução de textos aerotécnicos: Um estudo de caso em uma MRO. Aviation in Focus, 3, 67-75.

[25] Costa, C. E. P. and Camargo, D.C. (2016) A Corpus-Based Study of Simple Terms "Segurança", "Safety" and "Security" in Aviation Language. Aviation in Focus, 7, 4-12. https://doi.org/10.15448/2179-703x.2016.1.23738

[26] Terenzi, D. and Pantoja, M.T.B. (2018) A busca pela tradução de termos técnicos da área de manutenção de aeronaves: Um estudo exploratório. Revista CBTecLE, 1 , 21-32.

[27] Prado, M.C.A. (2010) Aviation Oral English Corpus in Abnormal Situations. Aviation in Focus, 1, 48-57.

[28] Prado, M.C.A. (2015) Levantamento dos padrões léxico-gramaticais do inglês para aviação: Um estudo vetorado pela Linguística de Corpus. Master's Thesis, Universidade de São Paulo, São Paulo.

[29] Prado, M.C.A. (2019) A relevância da Pragmática no ensino do inglês aeronáutico: um estudo baseado em corpora. Doctoral dissertation, Universidade de São Paulo, São Paulo.

[30] Santos, A.P. (2019) An Analysis of the Most Used Lexical Terms in Corpus-Based Emergency Situations. In: Pacheco, A., Ed., English for Aviation: Guidelines for Teaching and Introductory Research, EDIPUCRS, Porto Alegre, 189-211.

[31] Gabrielatos, C. and Sarmento, S. (2006) Central Modals in an Aviation Corpus Frequency and Distribution. Letras de Hoje-Estudos e Debates de Linguística, Literatura, e Língua Portuguesa, 41, 215-240.

[32] Sarmento, S. (2008) O uso dos verbos modais em manuais de aviação em inglês: Um estudo baseado em corpus. Tese de doutorado. Universidade Federal do Rio Grande do Sul, Porto Alegre.

[33] Bocorny, A. (2014) As unidades especializadas poliléxicas nominais (UEPNS) nos manuais de aviação. Alfa (São José do Rio Preto), 58, 645-676.

https://doi.org/10.1590/1981-5794-1409-6

[34] Bocorny, A.E.P. (2015) A utilização de um corpus de operações aeronáuticas (COPAER) para a descrição da linguagem de especialidade da aviação: subsídios para o ensino de ESP. In: Ibanos, A.M.T., Mottin, L.P., Sarmento, S. and Sardinha, T.B., Eds., Pesquisas e Perspectivas em Linguística de Corpus, Mercado de Letras, Campinas, 373-406.

[35] Zuppardo, M.C. (2013) A linguagem da aviação: Um estudo de manuais aeronáuticos baseado na Análise Multidimensional. ReVEL, 11, 6-25. 
[36] Prado, M.C.A. and Tosqui-Lucks, P. (2019) Designing the Radiotelephony Plain English Corpus (RTPEC): A Specialized Spoken English Language Corpus towards a Description of Aeronautical Communications in Non-Routine Situations. Research in Corpus Linguistics, 7, 113-128. https://doi.org/10.32714/ricl.07.06

[37] Sarmento, S. (2009) Linguística de Corpus e o desenvolvimento de material didático para inglês. In: Sarmento, S. and Freitas, A.L., Eds., $O$ ensino do inglês como língua estrangeira: Estudos e Reflexões II, EDIPUCRS, 259-290.

[38] Zafiharimalala, H. and Tricot, A. (2010) Text Signals in the Aircraft Maintenance Documentation. Proceedings of the 8th MAD: Signalling Text Organisation. http://andre.tricot.pagesperso-orange.fr/ZafiharimalalaTricot_MAD2010.pdf

[39] Prado, M.C.A. and Tosqui-lucks, P. (2019) Designing the Radiotelephony Plain English Corpus (RTPEC): A Specialized Spoken English Language Corpus towards a Description of Aeronautical Communications in Non-Routine Situations. Research in Corpus Linguistics, 7, 113-128. https://doi.org/10.32714/ricl.07.06

[40] Wang, X. (2019) Construction and Application of Aircraft Manufacturing Engineering English Corpus. Proceedings of the 92 nd International Conference on Cultures, Languages and Literatures, and Arts (CLLA 2019), Taipei, 15-17 August 2019, 292-296. https://webofproceedings.org/proceedings series/article/artId/11173.html

[41] Prado, M.C.A. (2018) A pesquisa refletida no ensino (e vice-versa): A Linguística de Corpus e o inglês aeronáutico. In: Scaramucci, M.V.R., Tosqui-Lucks, P. and Damião, S.M., Eds., Pesquisas sobre inglês aeronáutico no Brasil, Pontes Editores, Campinas, 69-88.

[42] Boulton, A., Carter-Thomas, S. and Rowley-Jolivet, E. (2012) Issues in Corpus-Informed Research and Learning in ESP. In: Boulton, A., Carter-Thomas, S. and Rowley-Jolivet, E., Eds., Corpus-Informed Research and Learning in ESP. Issues and Applications, John Benjamins, Amsterdam, 1-14. https://doi.org/10.1075/scl.52.01bou

[43] Cobb, T. and Boulton, A. (2015) Classroom Applications of Corpus Analysis. In: Biber, D. and Reppen, R., Eds., Cambridge Handbook of English Corpus Linguistics, Cambridge University Press, Cambridge, 478-497. https://doi.org/10.1017/CBO9781139764377.027

[44] Boulton, A. (2016) Integrating Corpus Tools and Techniques in ESP Courses. ASp, 69, 113-137. https://doi.org/10.4000/asp.4826

[45] Anthony, L. (2020) AntConc (Version 3.5.9). Waseda University, Tokyo. https://www.laurenceanthony.net/software 